\author{
P.M. Fochuk ${ }^{1}$, V.P. Shafranyuk ${ }^{2}$, A.I. Rarenko ${ }^{1}$, A.I. Kanak ${ }^{1}$ \\ Ye.S. Nikonuk ${ }^{3}$, Z.I. Zakharuk ${ }^{1}$
}

\title{
Effect of Ionizing Radiation on the Structure, Electro-Physical and Optical Characteristics of $\mathrm{Cd}_{1-\mathrm{x}} \mathrm{Zn}_{\mathrm{x}}$ Te Crystals
}

\author{
${ }^{\text {I} Y u r i y ~ F e d k o v i c h ' ~ C h e r n i v t s i ~ N a t i o n a l ~ U n i v e r s i t y, ~ 2, ~ K o t s i u b y n s k y i ~ S t r ., ~ C h e r n i v t s i, ~ 58012, ~ U k r a i n e ~}$ \\ E-mail:a.kanak@chnu.edu.ua \\ ${ }^{2}$ Bukovinian State Medical University, 2, Teatral'na Sq., Chernivtsi, 58002, Ukraine \\ ${ }^{3}$ National University of Water Management and Nature Resources, 11, Soborna Str., Rivne, 33028, Ukraine
}

\begin{abstract}
Based on X-ray studies, conditions for growth of high structural perfect $\mathrm{Cd}_{1-\mathrm{x}} \mathrm{Zn}_{\mathrm{x}} \mathrm{Te}(0,02 \leq \mathrm{x} \leq 0,1)$ crystals have been optimized. In obtained crystals, changes in the structure, electrical parameters and optical transmission at samples irradiation by $\gamma$-, $\beta$ - radiations were investigated. At ${ }^{60} \mathrm{Co}$ source $\gamma$-quanta irradiation with a dose of $\Phi$ $\geq 10^{5} \mathrm{~Gy}$, a slight decrease of samples' structure and optical transmission, an increase of holes concentration $p$ and a decrease of charge carrier mobility $\mu$ in $p$-type crystals was observed. Within 30-40 days, the values of $p$ and $\mu$ were relaxed to an initial ones. Changes in structural perfection, optical transmission and electrical parameters of samples irradiated by electrons were more significant.

Keywords: $\mathrm{Cd}_{1-\mathrm{x}} \mathrm{Zn}_{\mathrm{x}} \mathrm{Te}$ solid solutions, ionizing radiation, structure, $\mathrm{X}$-ray studies, optical transmission, electro-physical properties.
\end{abstract}

Article acted received 11.07.2018; accepted for publication 15.09.2018.

\section{Introduction}

Interest in $\mathrm{Cd}_{1-\mathrm{x}} \mathrm{Zn}_{\mathrm{x}} \mathrm{Te}$ solid solution crystals is caused by perspectives of their practical application as various optoelectronic devices. Recently, more and more attention has been paid to the use of solid solutions based on cadmium telluride with low zinc content as detectors of ionizing radiation $[1,2,3]$. The problem of perfect $\mathrm{Cd}_{1-\mathrm{x}} \mathrm{Zn}_{\mathrm{x}} \mathrm{Te}$ crystals fabrication with reproducible predefined parameters for the creation of ionizing radiation detectors is not yet solved [2]. Unfortunately, due to the disadvantages of this material quality, highresolution CdZnTe-spectrometers are limited in relatively small sizes, making them ineffective to detect the high photon energies and for weak radiation signals if the detector is at a distance from the object. In this regard, it is necessary to significantly improve the material quality for detectors by optimization the technology of their obtaining.

Since such detectors should work under intense irradiation, it is important to know how the parameters of the material and its surface are changed during the measurement. In [4], the behavior of the $\mathrm{Cd}_{0.9} \mathrm{Zn}_{0.1} \mathrm{Te}$ detector in an environment with an elevated radiation level was investigated by studying the effects on the defective states of the $\gamma$-irradiation induced material. The process of irradiated detectors restoration was studied by authors [5]. It has been shown that irradiation of $\mathrm{Cd}_{0.9} \mathrm{Zn}_{0.1}$ Te-detectors with an increase of ionizing radiation doses/fluences significantly effects on their spectroscopic performance. In the review of works about the change of the main characteristics of corpuscular and $\gamma$-radiation detectors during operation [6] it was noted that, despite the fact that stable radiation damages with prolonged irradiation accumulates gradually, the degradation of dosimetric and spectrometric properties can occur in a threshold way at high doses. Moreover, the CdTe degradation with $\gamma$-irradiation begins at lower doses than $\mathrm{Cd}_{1-\mathrm{x}} \mathrm{Zn}_{\mathrm{x}}$ Te. The effect of irradiation with different $\gamma$-quanta flows on the low-temperature photoluminescence of $\mathrm{Cd}_{1-\mathrm{x}} \mathrm{Zn}_{\mathrm{x}} \mathrm{Te}(\mathrm{x}=0.05)$ crystals $(\mathrm{x}=$ $0.05)$ were studied in $[7,8]$. It was found that $\gamma$-irradiation of $\mathrm{Cd}_{1-\mathrm{x}} \mathrm{Zn}_{\mathrm{x}} \mathrm{Te}$ crystals greatly changes the appearance of their low-temperature photoluminescence spectrum.

To correct the growth technology of large, perfect $\mathrm{Cd}_{1-\mathrm{x}} \mathrm{Zn}_{\mathrm{x}} \mathrm{Te}$ crystals, in this work, their structural perfection was investigated, depending on the growth 
conditions and the effect of ionizing radiation on the grown crystal parameters was studied.

\section{Experiment Methodology}

$\mathrm{Cd}_{1-\mathrm{x}} \mathrm{Zn}_{\mathrm{x}} \mathrm{Te}(0.02 \leq \mathrm{x} \leq 0.1)$ solid solutions were synthesized from the initial components in graphitized quartz ampoules. The ampoule was placed in a threezone furnace at an angle of $45^{\circ}$ to the horizon. When heated, the temperature of all zones was maintained the same. The heating was carried out to a temperature of $20 \mathrm{~K}$ above the melting point of the solid solution. After the melt homogenization and ampoule rotation around the axis for solution mixing, a temperature gradient was established along the ampoule and vertical directed crystallization was carried out by programmed reduction of the furnace power. A polycrystalline ingot with blocks stretched along the ampoule was obtained. Crystal growth and subsequent annealing of the ingot were carried out after its synthesis without ampoule depressurization. This allowed to avoid possible contamination of the material when it was restarted. Crystals were grown by the Bridgman technique. In this case, both a traditional and a modified setup, described in [9], were used. In a modified setup, a disturbance of monotonic container movement with the melt, which negatively affects on the grown crystal structure, was removed by the displacement of a massive heater relative to a stationary container with the material.

To improve the homogeneity of $\mathrm{Cd}_{1-\mathrm{x}} \mathrm{Zn}_{\mathrm{x}}$ Te crystal composition, the setup of crystal growth by zone melting at an angle to the horizon was also used. The furnace heater for growth consisted of several independent sections that gave the possibility to create various temperature profiles and controllably change the value of the temperature gradient at the crystallization front. In this setup, during growth, the cylindrical container with material was rotated around its axis. This led to the alignment of the crystallization front and the intense mixing of the melt.

To investigate the crystalline structure of as-grown crystals, the complementary methods such as X-ray diffraction topography in the reflection mode (the BergBarrett's method), in the transmission mode (the Lang's method) and the method of a double-crystal spectrometer (DCS) [10] were used. It should be noted that these methods are expressive, non-destructive and provide an opportunity to visualize the defects, arising during the growth process (twins, small-angular boundaries, dislocations, etc.), that allows to correct the technological growth processes.

The grown $\mathrm{Cd}_{1-\mathrm{x}} \mathrm{Zn}_{\mathrm{x}}$ Te ingots were oriented in (111) and (110) crystallographic planes, which were close to the growth axis. Crystallographic orientation of ingots and wafers, as well as determination of their surfaces disorientation were carried out by X-ray diffractometric method using the X-ray diffractometer DRON-ZM, goniometer GUR-8 and standard devices, which are included in the goniometer set.

Particular attention was paid to the wafers surface preparation for structure studying. Cutting, grinding, and mechanical polishing of crystals results in the appearance of a disturbed layer of the considerable depth, which distorts the material properties. The easiest way to remove a disturbed layer is deep chemical etching in an $8 \%$ solution of bromine in methanol, but this causes the surface relief appearance. This is due to the fact that the chemical etcher removes, in the first place, more disturbed parts of the single crystal, resulting in a surface with deep holes. Significantly reduce the depth of disturbed layer, without causing the surface pollution and the relief appearance it is possible by chemicalmechanical polishing (CMP) [11, 12]. Both methods of treatment were used in the samples preparation. CMP of $\mathrm{Cd}_{1-\mathrm{x}} \mathrm{Zn}_{\mathrm{x}} \mathrm{Te}$ samples was carried out by colloidalsiliceous compositions of the following composition: aminoetoxiaerosil (AEA), $\mathrm{H}_{2} \mathrm{O}_{2}, \mathrm{NaOH}, \mathrm{C}_{3} \mathrm{H}_{8} \mathrm{O}_{3}$. Use of an ultra dispersed AEA powders with size of 2-20 nm as abrasive material should not cause the significant damage of surface structure.

Thr technological processes of $\mathrm{Cd}_{1-\mathrm{x}} \mathrm{Zn}_{\mathrm{x}} \mathrm{Te}$ crystals growth were corrected by the results of X-ray diffraction studies. Structural studies of grown crystals were carried out by the modified Berg-Barrett's method using symmetric (111), (220), (333), (440) and asymmetrical reflections (422), (440), (511). In this method, a finefocus X-ray tube BSM-1 with copper and molybdenum anodes was used. Focus size was $50 \mu \mathrm{m}$ that made it possible to obtain a high resolution of $\sim 0.5 \mu \mathrm{m}$.

The Lang's method [10] gives the most accurate notion about the dislocation structure of $\mathrm{Cd}_{1-\mathrm{x}} \mathrm{Zn}_{\mathrm{x}} \mathrm{Te}$ crystals. However, dynamic oscillations with X-ray diffraction can only be obtained in the most perfect crystals on thin samples, in which $\mu t<1$, where $\mu$ is linear absorption coefficient, and $t$ is thickness of the sample $(130 \div 200 \mu \mathrm{m})$. Such $\mathrm{Cd}_{0.96} \mathrm{Zn}_{0.04}$ Te samples were manufactured by a special method, consisting in the fact that on one side in the middle of a flat-parallel wafer a 10 mm width groove was grinned to a depth of $1 / 3$ wafer thickness. On the opposite side, turning the wafer to $90^{\circ}$, the same groove was grinned to a depth of $1 / 3$ wafer thickness. As a result, at the intersection of the grooves, the "window" thickness in the center of the sample was of $1 / 3$ wafer thickness, and the matrix had the wafer thickness. Such method of samples manufacturing with a thin "window" for X-ray passage has made it possible to avoid their deformations at fastening during the research. The input surface of samples was perpendicular to the crystallographic directions [111].

Measurements of the lattice parameter $a$ were performed on the X-ray setup DRON by the Bond's method [10]. Measurement accuracy of value $a$ was within $\pm 0.00002 \mathrm{~nm}$.

For measurements of electrical characteristics, polished samples from the grown crystals were made in the form of rectangular parallelepipeds with size $(12 \times 2 \times 1,5) \mathrm{mm}^{3}$. Current contacts and two pairs of symmetrical Hall contacts to the samples were fabricated by deposition of a copper layer from a $\mathrm{CuSO}_{4}$ drop followed by In-Sn alloy soldering. Measurements were carried out on a direct current in magnetic field with an induction of $0.5 \mathrm{~T}$. Signals were fixed by an electrometer with an input resistance of $10^{12} \Omega$ and a sensitivity of 0.1 $\mathrm{mV}$. Specific electrical conductivity $\sigma$, the Hall coefficient $R_{\mathrm{H}}$ and Hall current carriers mobility of $\mu=$ 
$\sigma R_{\mathrm{H}}$ were investigated at temperature $T=290 \mathrm{~K}$.

Infrared transmission spectra in the wavelength range of 400-1150 $\mathrm{nm}$ were measured on an USB Ocean Optics 2000+ spectrophotometer with an optical resolution of $1.0 \mathrm{~nm}$. In the wavelength range of 2.4-25 $\mu \mathrm{m}$, infrared transmission spectra were measured on an IRS-29 spectrophotometer.

Irradiation by $\gamma$-quanta was carried out at the MRH$25 \mathrm{M}$ setup $\left({ }^{60} \mathrm{Co}\right.$ source, energy of $\gamma$-quanta was 1.17 $\mathrm{MeV}), \beta$-irradiation was carried using an "Argus" setup with a specific dose of $10^{10}$ electron $/ \mathrm{cm}^{2} \cdot \mathrm{s}$ (electron energy was $1 \mathrm{MeV}$ ).

\section{Results and their discussion}

The investigated $\mathrm{Cd}_{1-\mathrm{x}} \mathrm{Zn}_{\mathrm{x}} \mathrm{Te}$ crystals were characterized by non-uniform distribution of structure defects, both along the length and in the cross-section of ingots.

Surface quality of the samples depended heavily on the treatment technique. Fig. 1a shows the X-ray topogram of $\mathrm{Cd}_{0.96} \mathrm{Zn}_{0.04} \mathrm{Te}$ wafers after prolonged etching, which is obtained using a skew-asymmetric scheme on the reflection ( $\mathrm{CuK} \alpha$-radiation, input surface (111), reflection (511). In this scheme, such reflection planes were used when the angle between the input plane and the reflection plane was minimal, which makes it possible to reduce the extinction thickness that in turn allows us to detect the surface relief and structure defects in thin near-surface layers [13].

The best results were obtained treating the $\mathrm{Cd}_{1}$ ${ }_{\mathrm{x}} \mathrm{Zn}_{\mathrm{x}} \mathrm{Te}$ crystals' surfaces by the colloidal-siliceous composition. Fig. $1 \mathrm{~b}$ shows the topogram of the $\mathrm{Cd}_{0.96} \mathrm{Zn}_{0.04} \mathrm{Te}$ crystal surface after the chemicalmechanical polishing. Comparing the topograms presented in Fig. 1a and Fig. 1b, one can notice a large difference in the flat parallelism of the treated surfaces.

Topogram of a perfect crystal contains on positive the two parallel straight light stripes, which are fragments of the Cossel's cones $K \alpha_{1}$ and $K \alpha_{2}$ (Fig. 2,a). If distortions of the ideal structure are present in the crystal, they are manifested in the curvature of the atomic planes, the gradient of the lattice parameter, the presence of small-angular boundaries, twins, and others. Such defects lead to the curvature of the Cossel's lines, the formation of closed contours, an increase of their number to three or more (Fig. 2,b). These topograms were obtained on crystals grown by the traditional Bridgman method with cooling in the mode of the furnace cut-off. As it was found, crystals grown using a traveling heater, had a most perfect structure than those obtained on the traditional setup.

Obtaining of the large single crystals depends on the container shape. The highest yield of large monoblocks was observed when crystals growth in a cylindrical quartz container (diameter of 50-60 mm) with the double walls and flat bottom and heat sink located at the center of the container bottom [14]. With ampoule movement into the furnace cold part, the crystal nucleation was occurred at the point, where the heat sink was attached, and the subsequent growth - surrounded by a melt. Due to this, the pressure of the container walls on the crystal
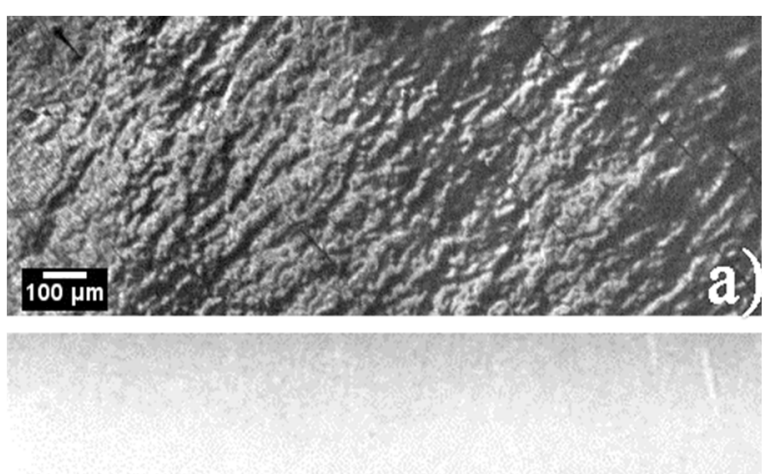

$100 \mu \mathrm{m}$

1)

Fig. 1. X-ray topograms of $\mathrm{Cd}_{0.96} \mathrm{Zn}_{0.04} \mathrm{Te}$ crystals surface after different treatment: a) chemical etching, b) chemical-mechanical polishing by the colloidalsiliceous composition.

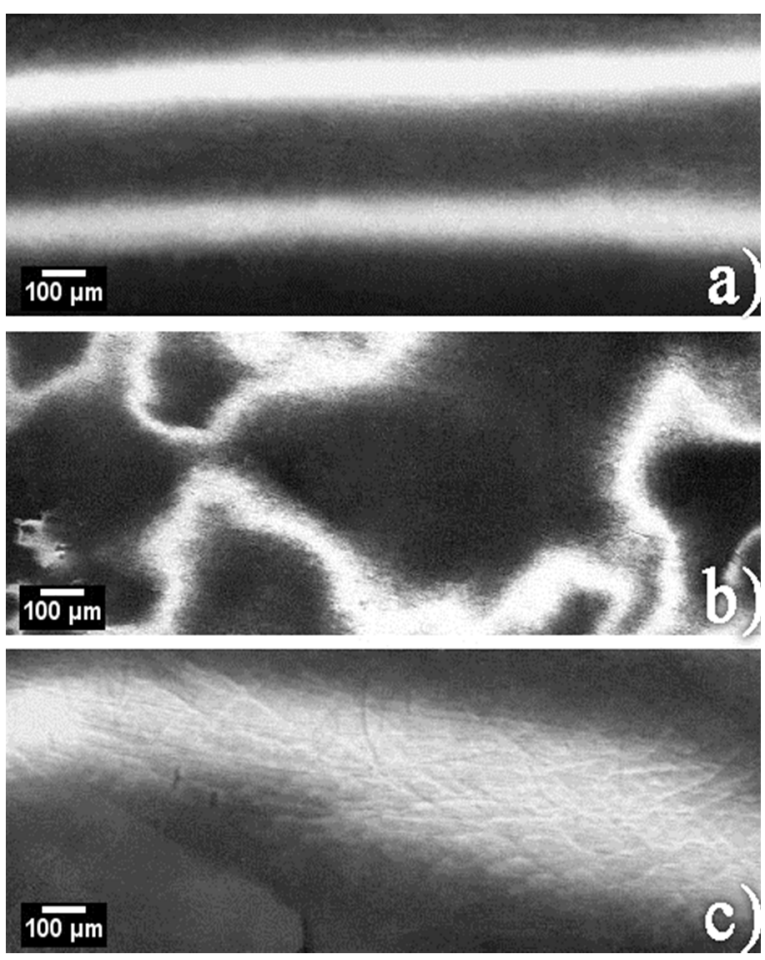

Fig. 2. X-ray topograms of $\mathrm{Cd}_{0.96} \mathrm{Zn}_{0.04}$ Te crystals: a) structural-perfect crystal, grown by an optimized technology; b) defective crystal, obtained by the traditional method; c) crystal with tensions due to heterogeneity of the lattice parameter. $\mathrm{CuK} \alpha_{1,2^{-}}$ radiation, reflection (333).

nucleus was eliminated and its structure became better. Fig. 2,a shows the topograms typical for $\mathrm{Cd}_{0.96} \mathrm{Zn}_{0.04} \mathrm{Te}$ crystals grown in such ampoules in a setup with a modified traveling heater. There was observed a clear separation of $\mathrm{K}_{\alpha 1}$ and $\mathrm{K}_{\alpha 2}$ doublets for different reflections, confirming the absence of macro-tensions, blocks, twins and others in crystals.

The homogeneity of the lattice parameter $a$ distribution along the cross-section and length of the $\mathrm{Cd}_{1-\mathrm{x}} \mathrm{Zn}_{\mathrm{x}} \mathrm{Te}$ ingots with a fixed value $x$, calculated for the 
loading of components, was researched. In all crystals grown by the modified Bridgman method, the value $a$ does not significantly change on the radial cross-section of ingots. A slight change in the value $a$ was found only in the cross-section of wide ingots (with the diameter greater than $30 \mathrm{~mm}$ ), have been cooled after growth at the rate exceeded $100 \mathrm{~K} / \mathrm{h}$.

Significant change in the value $a$ (up to $10 \%$ ) is observed along the axis of ingots. Optical studies have shown that an increase of the limiting wavelength value of the optical transmission along the ingot from the beginning of growth to the end occurs. The change in the solid solution composition along the length is particularly significant at higher zinc content $(\mathrm{x}>0.04)$. In such crystals, the heterogeneity of the value $a$ causes tension in the crystalline lattice (Fig. 2,c). To alignment the ingot composition, a long (48 $\div 30$ hours) annealing of $\mathrm{Cd}_{1-\mathrm{x}} \mathrm{Zn}_{\mathrm{x}}$ Te crystals was carried out at temperatures from $1370 \mathrm{~K}$ to $1000 \mathrm{~K}$ immediately after growth in the Bridgman setup. With such annealing it was succeeded to decrease the heterogeneity on value $a$ up to $5 \%$.

Homogeneity of value $a$ along the ingots' axis was ensured with the crystals growth by the method of zone melting with the rotation of a cylindrical container with material around its axis at an angle to the horizon. In such conditions, almost uniform distribution of components throughout the volume was provided. However, monoblocks in ingots grown by such method were smaller than in crystals obtained by the modified Bridgman method in ampoules of a special form.

$\mathrm{Cd}_{1-\mathrm{x}} \mathrm{Zn}_{\mathrm{x}} \mathrm{Te}$ crystal samples, which did not contain blocks, twins were investigated using DCS. Quantitative estimation perfection degree of these crystals was performed by comparing experimentally obtained full width of half maximum (FWHM) values of the rocking curves $\theta_{\text {exp }}$ with the theoretically calculated values $\theta_{\text {theor }}$. So, for reflections (111), (220), (440), (422) of the ideal $\mathrm{Cd}_{1-\mathrm{x}} \mathrm{Zn}_{\mathrm{x}} \mathrm{Te}$ crystal, the theoretical value of FWHM rocking curves respectively was equal to $\sim 24.7,17,13$ and 16.5 seconds. For real $\mathrm{Cd}_{1-\mathrm{x}} \mathrm{Zn}_{\mathrm{x}}$ Te crystals: $\theta_{\exp }>$ $\theta_{\text {theor }}$ due to the presence of such defects as dislocations, inclusion, micro-distortion. Via broadening of the rocking curves $\Delta \theta$, the density of dislocations $N_{d}$ was determined, which was a quantitative integral estimation of the crystal perfection:

$$
N_{d}=\frac{\Delta \theta^{2}}{9,42 \cdot b^{2}},
$$

where $\Delta \theta=\left(\theta_{\exp }^{2}-\theta_{\text {theor }}^{2}\right)^{1 / 2}, \quad \stackrel{r}{b}$ is a Burgers vector. Studies have shown that the average dislocations density in large blocks is within the range of $4 \times 10^{3} \div 10^{5} \mathrm{~cm}^{-2}$.

$\mathrm{Cd}_{0.96} \mathrm{Zn}_{0.04} \mathrm{Te}$ samples selected for irradiation had a high structural perfection and homogeneity, and the FWHM values of the rocking curves were close to the theoretical $\sim 25$ seconds for (111) (Fig. 4, curve 1). Fig. 3 shows the topograms (MoK $\alpha$-radiation, reflection $(\overline{4} 22)$ ) of such samples before and after $\gamma$-irradiation. On the topogram before irradiation, the dislocation network of high intensity lines are clearly visible (Fig. 3a). The accumulation of existing dislocations leads to the formation of wide dislocation glide stripes, which appear on the topograms in the form of triangles that is characteristic for high-perfect $\mathrm{Cd}_{1-\mathrm{x}} \mathrm{Zn}_{\mathrm{x}} \mathrm{Te}$ crystals with dislocation density $<10^{4} \mathrm{~cm}^{-2}$. It should be noted that the dislocations contrast will be maximum, when the diffraction vector $\stackrel{r}{g}$ and the Burgers vector $b$ will be parallel and will be zero when they are mutually perpendicular. After irradiation by the dose of $10^{5} \mathrm{~Gy}$, the $\mathrm{Cd}_{0.96} \mathrm{Zn}_{0.04} \mathrm{Te}$ sample structure varied, as evidenced by the blurriness of the dislocation image, which is related to the stresses gradient on the sample thickness (Fig. 3b).

Due the results obtained after $\gamma$-irradiation, we can conclude that an increase in the radiation dose to $\Phi \sim 10^{4}$ Gy leads to an increase in the thickness of the disturbed layer (up to 0.2 microns). This is appropriately represented on the broadening of the reflected $\mathrm{CuK} \alpha$ reflexes at different reflection orders, as well as the change in the shape of the rocking curves and increase of their FWHM (Fig. 4, curve 3). After removing of this disturbed layer by chemical etching, it is observed a decrease of the rocking curves' FWHM (Fig. 4, curve 2), the growth of the coherent reflection component, as well as a clearer image of the Cosseil's CuK $\alpha_{1,2}$-lines, indicating an improvement in the samples structure after irradiation.

The results obtained can be explained by the fact that the primary radiation defects generated during irradiation of $\mathrm{Cd}_{0.96} \mathrm{Zn}_{0.04}$ Te crystals are thermally unstable and sufficiently mobile. In the process of migration on the crystal, they can annihilate, or form more stable complexes with each other and with impurity atoms. In the case of high-energy $\gamma$-irradiation, Frenkel's or Schottky-type point defects predominate. Since such samples contain high concentrations of dislocations, microdefects and point defects, so $\gamma$-irradiation action leads to an activation of annihilation processes and a more even redistribution of defects.

Thus, the given results of studies in the case of $\gamma$ irradiation dose action $\left(\Phi \sim 10^{4}\right.$ Gy) testify the insignificant structural changes in crystals of CdTe-based solid solutions, at what the structural perfection degree in bulk even increases somewhat. This is confirmed by the
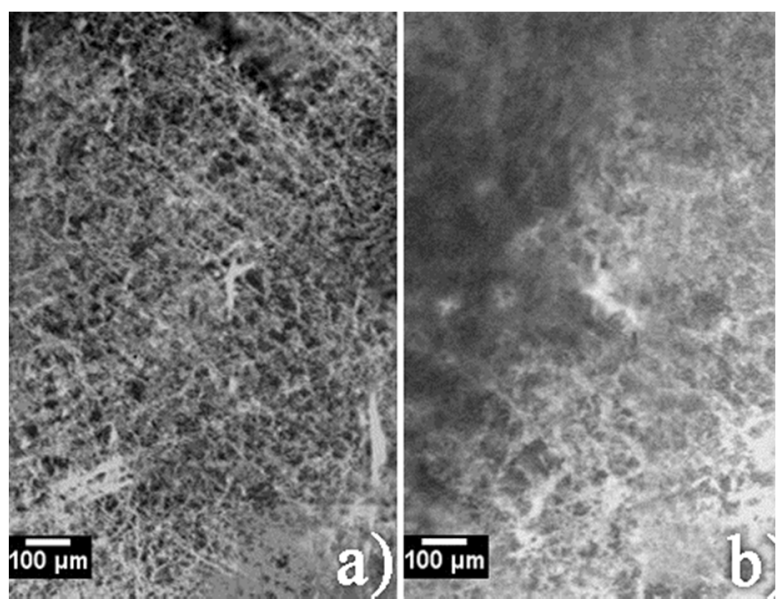

Fig. 3. X-ray topograms, obtained by the Lang's method, of $\mathrm{Cd}_{0.96} \mathrm{Zn}_{0.04} \mathrm{Te}$ samples: a) before irradiation, b) after $\gamma$-irradiation. 


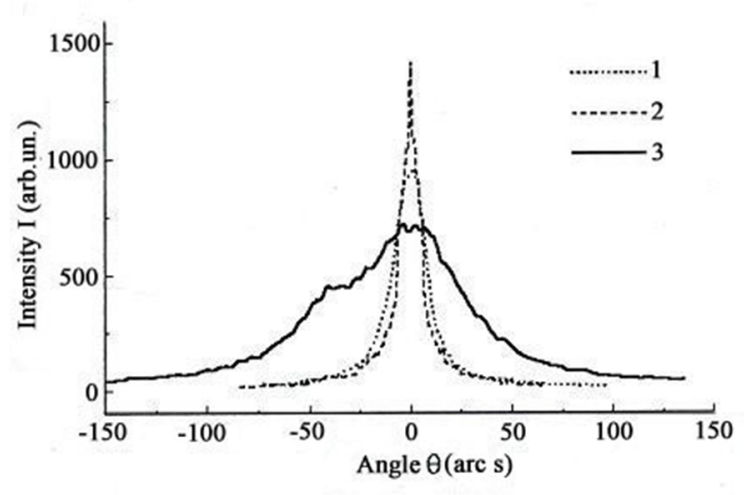

Fig. 4. X-ray diffraction rocking curves $(\mathrm{CuK} \alpha-$ radiation, reflection (111)), obtained on $\mathrm{Cd}_{0.96} \mathrm{Zn}_{0.04}$ Te samples: 1 - before irradiation; 2 after removing of the $\gamma$-irradiated sample disturbed layer; 3 - after $\gamma$-irradiation $\left(\Phi \sim 10^{4} \mathrm{~Gy}\right.$ ).

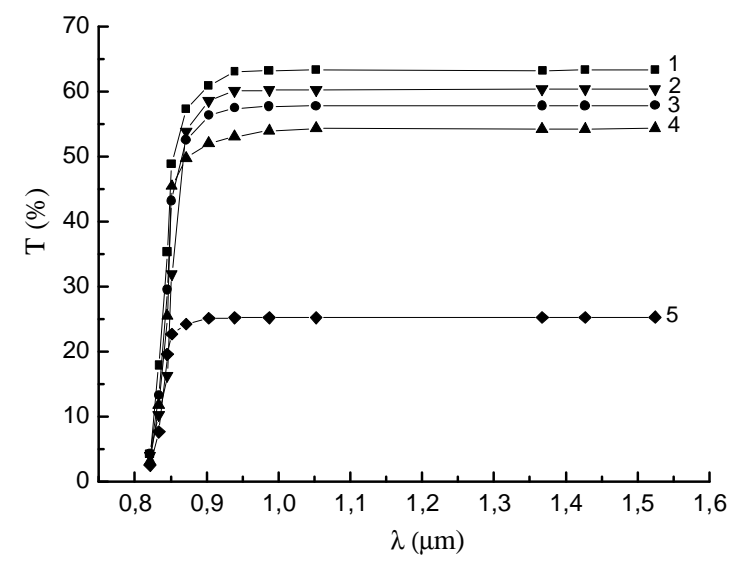

Fig. 5. Spectral dependence of optical transmission of $\mathrm{Cd}_{0,96} \mathrm{Zn}_{0,04} \mathrm{Te}$ samples with $1 \mathrm{~mm}$ thickness before and after irradiation: 1 - $\gamma$-irradiation, $\Phi \sim 10^{4}$ Gy (after additional polishing); 2 - before irradiation; 3 - $\gamma$-irradiation, $\Phi \sim 10^{4}$ Gy (without additional polishing); 4 - $\gamma$-irradiation, $\Phi \sim 10^{5} \mathrm{~Gy}$; 5 - $\beta$-irradiation, $\Phi=2 \times 10^{17} \mathrm{n} / \mathrm{cm}^{2}$.

results of optical studies of $\gamma$-irradiated samples $\left(\Phi \sim 10^{4}\right.$ Gy), in which a slight increase of optical transmission after removing of the disturbed layer is observed (Fig. 5, curve 1).

Measurements of the spectral transmission dependence of $\gamma$-irradiated samples $\left(\Phi \sim 10^{5}\right.$ Gy) were carried out. They were maintained at room temperature for a month. If, immediately before the measurement, the surface of such samples was polished to remove the nearsurface layer, then the crystal transparency increased at $77 \mathrm{~K}$. This means that while preserving irradiated crystals, part of the radiation defects from the bulk diffuses to the surface, forming a near-surface thin (40$80 \mu \mathrm{m}$ ) region that absorbs light intensely in a wide spectral range of wavelengths. It should be noted that the polishing of the control non-irradiated sample practically did not affect its transparency. The surface irradiated in this case acts as a getter that results in an improvement of the crystalline material structure.

The change in the optical transmission of infrared radiation and the $\mathrm{Cd}_{0.96} \mathrm{Zn}_{0.04}$ Te samples structure is caused by $\beta$-irradiation with doses of $10^{15}$ to $10^{16} \mathrm{~cm}^{-2}$. Complementary $\mathrm{X}$-ray and optical researches have shown that in crystals irradiated with such doses there is an increase of radiation defects concentration in the crystal bulk, as evidenced by changes in the rocking curves and the absorption coefficient (Fig.5, curve 5). Such changes of optical properties after irradiation can not be explained by the influence of only one tails of states density arising as a result of fluctuations of the random electric field of charged defects. The change in the lattice state in irradiated samples may cause an internal mechanical stresses and defects that arose due to irradiation. After irradiation, the structure of $\mathrm{Cd}_{0.96} \mathrm{Zn}_{0.04} \mathrm{Te}$ crystals is markedly worsening, as evidenced by the blurriness of the dislocation image (Fig. $3 \mathrm{~b}$ ), which is related to the stresses gradient along sample thickness.

Consequently, optical studies of samples showed that $\beta$ - and $\gamma$-irradiated crystals differ by the concentration of radiation defects in the crystal bulk, which is much larger in $\beta$-irradiated samples, as evidenced by the change in optical transmission in the region of intrinsic absorption edge (Fig. 5). It is possible that in $\beta$-irradiated crystals some accumulations of defects (clusters) are formed, which due to their disintegration, when irradiated samples are stored, enrich the lattice by shallow mobile donors.

Changes in electro-physical properties were investigated before and after irradiation with $\gamma$-quanta energies of the ${ }^{60} \mathrm{Co}$ source (by dose of $\Phi \sim 10^{5} \mathrm{~Gy}$ ). Immediately after irradiation in the region of impurity conductivity, an increase in the concentration of holes $p$ in $p$-type crystals was found. Decrease of the charge carriers mobility $\mu$ from $60-65 \mathrm{~cm}^{2} / \mathrm{V} \cdot \mathrm{s}$ to $50-55 \mathrm{~cm}^{2} / \mathrm{V} \cdot \mathrm{s}$ took place. These changes are unstable, and for a long time (30-40 days) the values of $p$ and $\mu$ are relaxed to the initial ones. This can be explained by mechanism of $\gamma$ stimulated transformation of defects: $\gamma$-irradiation results in the formation of Frenkel' pairs (predominantly $\mathrm{Cd}_{\mathrm{i}}+$ $\mathrm{V}_{\mathrm{Cd}}$ ) whose components migrate to the runoffs at different rates. Due to the higher diffusion rate to the interstitial cadmium runoffs, the crystal bulk immediately after radiation is enriched with acceptors $\mathrm{V}_{\mathrm{Cd}}$, resulting in corresponding changes of the free carrier concentration in the region of impurity conduction. Relaxation of $\gamma$ stimulated changes $(p, \mu)$ has a complicated nature and takes place in 2 stages: release of bulk from residual $\mathrm{V}_{\mathrm{Cd}}$ due to the migration on runoffs (within 7-10 days) and annihilation of pairs at runoffs (within 30-40 days). Formation of electrically active complexes, stable for a longer time, was not detected.

Electron irradiation results in a much larger change in the electrical parameters of $\mathrm{Cd}_{0.96} \mathrm{Zn}_{0.04} \mathrm{Te}$. After irradiation in p-type samples, the mobility of charge carriers falls from $60-65 \mathrm{~cm}^{2} / \mathrm{V} \cdot \mathrm{s}$ to $20-25 \mathrm{~cm}^{2} / \mathrm{V} \cdot \mathrm{s}$. The material becomes highohmic and heterogeneous. 


\section{Conclusions}

Based on X-ray studies of structure, growth methods of high structural perfection $\mathrm{Cd}_{1-\mathrm{x}} \mathrm{Zn}_{\mathrm{x}} \mathrm{Te}(0.02 \leq \mathrm{x} \leq 0.1)$ crystals were optimized.

With samples irradiation of grown $\mathrm{Cd}_{0.96} \mathrm{Zn}_{0.04} \mathrm{Te}$ crystals by ${ }^{60} \mathrm{Co}$ source $\gamma$-quanta with a dose of $10^{4} \mathrm{~Gy}$, changes in structural perfection and optical transmission were not significant. Irradiation by a larger dose $\left(\Phi \sim 10^{5}\right.$ Gy) results in worsening of samples' structure and optical transmission, an increase of holes concentration $p$ in $p$-type crystals, and a decrease of charge carrier mobility. These changes are unstable, the values of $p$ and $\mu$ relaxe to an initial ones within 30-40 days. There was observed the diffusion of a part of radiation defects from the bulk to surface. The number of radiation defects is higher in the samples irradiated by electrons, resulting in a decrease of the infrared radiation transmission, the material becomes highohmic and heterogeneous.
The authors express their gratitude to the employees of the radiation department of the NASU Institute of Physics for conducting of samples irradiation.

Fochuk P.M. - doctor of chemistry, professor, vice rector for scientific work and international relations;

Shafranyuk V.P. - candidate of physical and mathematical sciences, associate professor;

Nikonuk E.S. - candidate of physical and mathematical sciences, associate professor;

Zakharuk Z.I. - Senior Research Fellow;

Rarenko G.I. - Candidate of Sciences (Physics and Mathematics), Senior Researcher;

Kanak A.I. - Candidate of Chemical Sciences.

[1]. A. E. Bolotnikov, J. Butcher, G. S. Camarda, Y. Cui, G. De Geronimo, J. Fried, P. M. Fochuk, et al., IEEE Trans. Nucl. Sci., 60(4) (2013) 2875.

[2]. Mohd. Shkir, V. Ganesh, S. AlFaify, A. Black, E. Dieguez, G. Bhagavannarayana, J. Alloys Compd., 686, (2016) 438.

[3]. P. Fochuk, Y. Nykoniuk, Z. Zakharuk, O. Kopach et al., IEEE Trans. Nucl. Sci., 64(10) (2017) 2725.

[4]. A. Cavallini, B. Fraboni, W. Dusi, M. Zanarini, P. Siffert, Appl. Phys. Lett. 77(20) (2000) 3212.

[5]. B. Fraboni, A. Cavallini, N. Auricchio, et al, Semiconductor Sci. and Techn., 21(8) (2006) 1034.

[6]. L. N. Davydov et al. Bull of KhNU, 627, Iss. 'Physics', 1(26) (2005) 3.

[7]. K. D. Glynchuk, N. M. Lytovchenko, Y. M. Naseka, A. V. Prokhorovych et al., Ukr. Phys. Journ., 55(7) (2010) 777.

[8]. N. M. Lytovchenko, Y. N. Naseka, A. V. Prokhorovych et al. Optoelectronics and Semicond. Tech., 45, (2010) 54.

[9]. Ye. S. Nykonyuk, Z. I. Zakharuk, A. I. Rarenko, et al., J. Nano- and Electron. Phys., 7(4) (2015) 04054.

[10]. V. V. Lider, Zavodskaya laboratoria, Diagnostika materialov, 73(12) (2007).

[11]. O. N. Krylyuk, I. M. Rarenko, Z. I. Zakharuk, Patent pf Ukraine No 1773083, date: 1.07.1992 reg. no.: 4780730 (1990).

[12]. S. G. Dremlyuzhenko, Z. I. Zakharuk, A. I. Savchuk, and P. M. Fochuk, Phys. stat. sol. (b)., 244(5) (2007) 1650.

[13]. S. A. Kshevetsky, Y. P. Stetsko, I. M. Fodchuk et al., Ukr. Phys. Journ., 35(3) (1990) 344.

[14]. Z. I. Zakharuk, A. I. Rarenko, E. V. Rybak, et al., Physics and Chemistry of Solid State, 8(1) (2007) 25. 
П.М. Фочук ${ }^{1}$, В.П. Шафранюк², Г.І. Раренко ${ }^{1}$, С.С. Никонюк ${ }^{3}$, А.I. Канак ${ }^{1}$, 3.I. Захарук ${ }^{1}$

\section{Вплив іонізуючого випромінювання на структуру, електрофізичні i оптичні характеристики кристалів $\mathrm{Cd}_{1-\mathrm{x}} \mathrm{Zn}_{\mathrm{x}} \mathrm{Te}$}

\footnotetext{
${ }^{1}$ Чернівецький національний університет імені Юрія Федьковича, вул. Коиюбинського, 2, Чернівці, Україна 58012,e-mail: a.kanak@chnu.edu.ua

${ }^{2}$ Буковинський державний медичний університет, пл. Театральна, 2, 58002 Чернівиі, Україна, e-mail: microel-dpt@chnu.edu.ua

${ }^{3}$ Національний університет водного господарства та природокористування, вул. Соборна, 11, 33028 Рівне, Україна, е-mail: semirivne@gmail.com

На основі рентгенівських досліджень були оптимізовані умови вирощування кристалів $\mathrm{Cd}_{1-\mathrm{x}} \mathrm{Zn}_{\mathrm{x}} \mathrm{Te}$ $(0,02 \leq \mathrm{x} \leq 0,1)$ високої структурної досконалості. В одержаних кристалах досліджені зміни структури, електричних параметрів і оптичного пропускання при опромінені зразків $\gamma$-, $\beta$ - випромінюванням. При опромінені $\gamma$-квантами джерела ${ }^{60}$ Со дозою $\Phi \geq 10^{5}$ Гр спостерігалося незначне погіршення структури $\mathrm{i}$ оптичного пропускання зразків, збільшення концентрації дірок $p$ і зменшення рухливості носіїв заряду $\mu$ в кристалах $p$-типу. Протягом 30 - 40 діб значення $p i \mu$ релаксували до вихідних значень. Зміни структурної досконалості, оптичного пропускання і електричних параметрів зразків, опромінених електронами, були більш суттєвими.

Ключові слова: тверді розчини $\mathrm{Cd}_{1-\mathrm{x}} \mathrm{Zn}_{\mathrm{x}} \mathrm{Te}$, іонізуюче випромінювання, структура, рентгенівські дослідження, оптичне пропускання, електрофізичні властивості
} 